\title{
Rupture point analysis of intestinal anastomotic healing in rats under the action of pure Copaíba (Copaifera Iangsdorfii) oil ${ }^{1}$
}

\author{
Análise do ponto de ruptura na cicatrização de anastomose intestinal em ratos tratados com óleo \\ de Copaíba (Copaifera Iangsdorfii) puro
}

\author{
Ernesto Comelli Júnior', James Skinovski ${ }^{\mathrm{II}}$, Marcos Fabiano Sigwalt ${ }^{\mathrm{II}}$, Alessandra Borges Branco ${ }^{\mathrm{III}}$, Sheila Rampazzo Luz ${ }^{\mathrm{IV}}$, \\ Cíntia de Paula Baulév \\ ${ }^{I} \mathrm{MD}$, Resident, Experimental Surgery Group, UP, Curitiba-PR, Brazil. \\ ${ }^{\text {II }} \mathrm{PhD}$, Full Professor of Clinical Surgery, Operative Technique and Experimental Surgery Division, Surgery Department, UP, Curitiba-PR, Brazil.

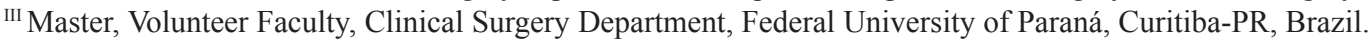 \\ ${ }^{\mathrm{IV}} \mathrm{MD}$, Experimental Surgery Group, UP, Curitiba-PR, Brazil. \\ ${ }^{\mathrm{v}}$ Graduate student, Experimental Surgery Group, UP, Curitiba-PR, Brazil.
}

\begin{abstract}
Purpose: Analyze the mechanical strength of digestive tract scar after intestinal anastomosis surgery in animals treated with pure Copaíba oil. Methods: 60 Wistar rats, male, about 250 days old and weighting around $350 \mathrm{~g}$ were used. The rats were randomly divided into two groups: Group O, with 30 animals that received Copaíba oil and Group C, with 30 animals that received saline. Each group was subdivided into three subgroups, containing 10 rats each. They were designated O7, O14, O28, C7, C14 and C28, according to the post-operative assessment date at 7, 14 and 28 days, respectively. On these dates euthanasia was performed with the removal of the bowel segment containing the anastomosis and assigning the samples to tensile test for assessing Maximum Stress, Maximum Tensile Strength and Maximum Rupture Strength. Results: On the three variables of the study, the results indicate that, for the three assessment periods (7, 14 and 28 days) there was no significant difference between the oil and control groups. Conclusion: For the mechanical tests proposed by this study, Copaíba oil didn't show any effectiveness in increasing the anatomosis strength.
\end{abstract}

Key words: Fabaceae. Anastomosis, Surgical. Wound Healing. Phytotherapy.

\section{RESUMO}

Objetivo: Analisar a resistência mecânica da cicatriz do tubo digestivo, após cirurgia de anastomose intestinal em animais tratados com óleo da Copaíba puro. Métodos: Foram utilizados 60 ratos Wistar, machos, com cerca de 250 dias e peso médio de $350 \mathrm{~g}$. Os ratos foram divididos aleatoriamente em dois grupos: Grupo O, com 30 animais, que receberam óleo da Copaíba e Grupo C, com 30 animais, que receberam solução físiológica. Cada grupo foi subdividido em três subgrupos, contendo 10 ratos cada. Suas denominações foram O7, O14, O28, C7, C14 e C28, segundo o tempo de avaliação pós-operatória em 7, 14 e 28 dias, respectivamente. Nessas datas foi realizada a eutanásia com a retirada do segmento intestinal contendo a anastomose, destinando as amostras ao teste de tração para a apreciação da Tensão Máxima, Força Máxima de Tração e Força Máxima de Ruptura. Resultados: Nas três variáveis do estudo, os resultados indicam que, para os três momentos de avaliação $(7,14$ e 28 dias) não houve diferença significativa entre os grupos óleo e controle. Conclusão: Para os testes mecânicos a que este estudo se propôs o óleo de Copaíba não se mostrou eficaz em aumentar a resistência da anatomose.

Descritores: Fabaceae. Anastomose Cirúrgica. Cicatrização de Feridas. Fitoterapia.

${ }^{1}$ Research performed at the Experimental Surgical Center, Operative Technique and Experimental Surgery Division, Surgery Department, Positivo University (UP), Curitiba-PR, Brazil.

\section{Introduction}

Surgical intervention on intestinal injuries long became that day-to-day procedures of surgical practice, either due to trauma or due to numerous diseases. The healing process is very important in this type of surgery, given the high risk of complications, such as: suture dehiscence, fistula and severe abdominal infections by the intestinal bacterial flora, leading to high rates of morbidity and mortality. For this reason, many techniques and materials have been used to make digestive tract anastomoses safer and more effective ${ }^{1}$. Due to its importance, the healing process in intestinal surgery has been studied in its broader aspects.

The complications related to intestinal anastomosis are more frequent in the first week after surgery, when the anastomotic tensile strength depends mainly of collagen fibers produced by 
fibroblasts, present mainly in the digestive tract submucosal layer, which hold the suture and support the intestinal wall. After this initial period, the supply of collagen fibers increases along the immune and humoral system performance, restoring the normal tissue tensile ${ }^{2}$.

This healing process includes three distinct, well known, overlapping and interdependent phases: inflammatory, proliferative and maturation ${ }^{2,3}$.

However, some factors such as anastomosis technique, presence of infection, postoperative care, individual immunity, blood supply, bacterial flora, inflammatory response, age and nutritional status interfere with the scar strength and anastomosis integrity ${ }^{3-5}$. Currently, new research lines are investigating other agents or conditions that might interfere with the healing phases or directly in the collagen metabolism, leading to a healing process deficiency, as described by Biondo-Simões et $a l .{ }^{6}$ in a test study with hypothyroid animals, where it was reported delayed maturation of the scars in intestinal anastomosis decreasing the production of collagen type I and III.

For this reason, research on substances that speed up the healing process, increase scar strength and at the same time, develop minimal side effects, have been growing considerably in recent years, attracting attention from the pharmaceutical industry.

Studies on herbal medicines in Northern Brazil, with anti-inflammatory and healing action on skin wounds, have been well documented in the medical literature ${ }^{7}$, especially resin extracted from the trunk of the Copaíba (Copaifera Iangsdorfii), tree of the Fabaceae family.

Recent studies have demonstrated clear therapeutic effects of this oil as an inflammation inhibition agent, healing process accelerator in open wounds and even antinociception ${ }^{8,9,10}$. In that area, new lines of research have been developed to analyze the Copaíba oil chemicals components associating them with their pharmacological effects. There are, for example, evidence of healing and anti-inflammatory activity in certain fractions of diterpenes, sesquiterpenes, kaurenoic and polyaltic acids, present in pure oil. Those are responsible for speeding up to day 9 the healing in open wounds and to day 5 in cases of wounds by incisions ${ }^{7}$.

Despite the widespread use of Copaíba oil in popular medicine and its proven healing effect on open wounds, what is known about the effects on the healing process development is not yet clearly explained scientifically, especially on issues related to intestinal anastomosis. Therefore, this study sought to evaluate, from a mechanical strength perspective, the effects of Copaíba oil on the healing of intestinal anastomosis in Wistar rats.

\section{Methods}

The study was approved by the Positivo University Ethics and Research on Animals Committee, under the protocol $\mathrm{n}^{\circ}$ 08/2006 and performed in conformance with Federal Law n ${ }^{\circ} 11.794$, from October 08, 2008 $8^{11,12}$.

\section{Sampling}

To perform this experiment 60 male Wistar rats (Rattus norvegicus albinus) were used, with age ranging from 200 to 250 (mean 225 days), coming from Positivo University's biolab and whose weights ranged from 320 to $390 \mathrm{~g}$.

The animals were housed in pairs in standard lengths polypropylene cages and maintained in a cycle of 12 hours of daylight and 12 hours of darkness and constant temperature of $24^{\circ} \mathrm{C}$.

The animals were fed with adequate diet and had access to water ad libitum during the experiment.

\section{Procedures}

The animals were subjected to fasting for 12 hours prior surgery, being kept free access to water. The surgery took place the next day.

The rats received inhalation anesthetic induction by Halotene vaporization, in closed hood, being considered anesthetized when they showed no reaction to handling. After that, they were anesthetized via Ketamine Chloride 10\% intramuscular, at a dose of $100 \mathrm{mg} / \mathrm{kg}$ body weight and Xylazine Chloride $2 \%$, at a dose of $10 \mathrm{mg} / \mathrm{kg}$ body weight.

The anesthetic dosage applied was considered appropriate observing the amplitude and frequency of their respiratory movements and reflex to pain. After the anesthetic induction, were noted in the protocol form the animal's group and subgroup and the date of surgery.

Followed the ventral abdominal wall trichotomy. Then, the fixing of the animal with adhesive tape, in the surgical pad on supine position, and keeping its members extended. Then, it was performed the thoracic-abdominal antisepsis with polyvinylpyrrolidone-iodine solution at $10 \%$ and abdomen delimitation with sterile surgical drapes.

There was a midline incision $4 \mathrm{~cm}$ long, using scalpel \#15, starting from the end of the xiphoid process and addressing the caudal direction, involving all tiers of the ventral abdominal wall. Thereby obtaining operative access to peritoneal cavity. Then, it was examined the small intestine segment to be approached, common to all animals, identifying the intestinal ring segment $10 \mathrm{~cm}$ from the duodenojejunal flexure. Then it was carried out a cross section of it (Figure 1), and followed a terminal-end anastomosis, using polypropylene monofilament thread 6-0 (needle 3/8), at suture single layer, with separate total stitches, closed with four internal tied semi-knot on the mucosa ${ }^{13}$, totalizing eight points (Figure 2). The anastomosis was protected with sterile wet gauze to cause a lesser trauma to the intestinal ring. After that, the intestine was returned to its normal position in the abdominal cavity. The abdomen wall was sutured with two suture lines, in continuous whipstitch, the first, peritoneum-muscular-aponeurotic, and the second, the skin one; using for it polyglactin multifilament thread 3-0.

Right after surgery, the animals received subcutaneous opioid analgesic (Morphine) in a single dose of $2.8 \mathrm{mg} / \mathrm{kg}$, in order to prevent postoperative pain at the surgical site.

The animals were then transferred to appropriated cages, identified by group and subgroup for postoperative follow-up, and observed until recovery of their normal motor activity, and transferred to the original cages, previously identified and at environmental conditions similar to the preoperative period.

The choice of groups was made randomly: Group O, with 
30 animals that received pure Copaíba oil from the Amazon, and Group C (control), with 30 animals that received saline $0.9 \%$. Each group was subdivided into three subgroups containing 10 rats each. They were designated O7, O14, O28, C7, C14 and C28, according to the postoperative assessment date, i.e, after 7, 14 and 28 days, respectively.

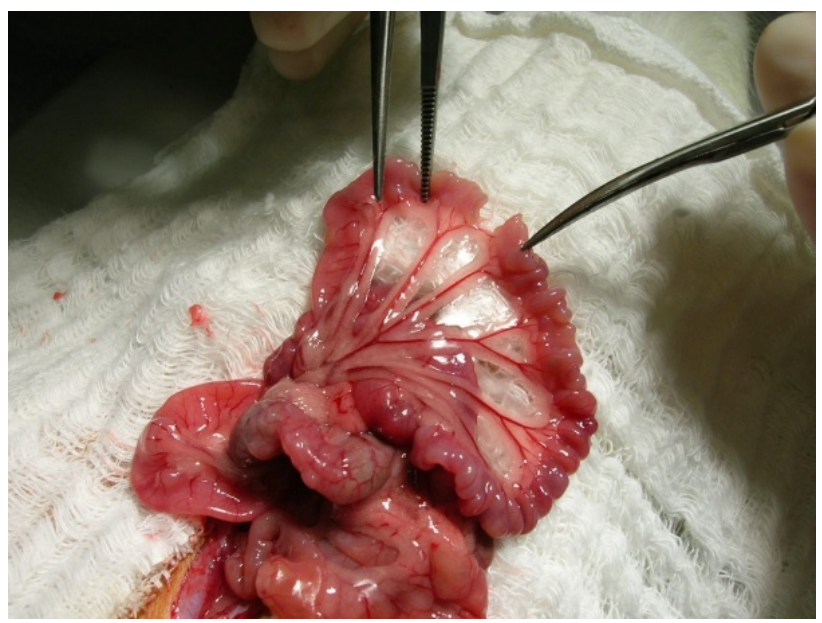

FIGURE 1 - Intestinal region sectioned for performance of the anastomosis.

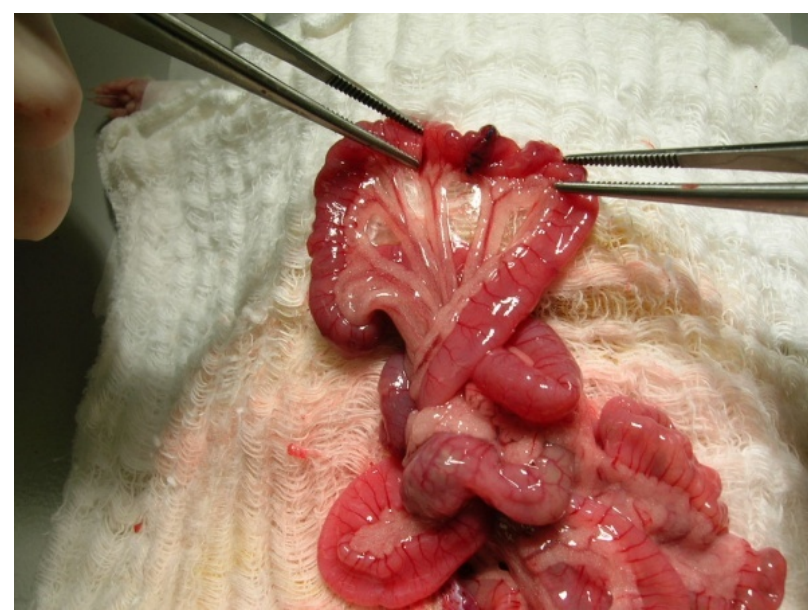

FIGURE 2 - Terminal-end anastomosis performed on 8 internal tied separated points.

During the first seven days after surgery, each group received analgesic and antipyretic, diluted in water (acetaminofene drops, $200 \mathrm{mg} / \mathrm{ml}$ ).

The rats had free access to water immediately, while ration was given 12 hours after the surgical procedure.

The Copaíba oil administration in group $\mathrm{O}$ animals was performed via gavage at doses of $0.42 \mathrm{ml} / \mathrm{kg}$ weight, once a day, for the given periods after surgery procedure. That dose was based on popular indication for therapeutic usage, suggesting daily usage of 1 tablespoon a day (around $10 \mathrm{~mL}$ ) which, being applied the correction factor to a rodent metabolism $(\mathrm{f}=3)^{14}$, correspond to a volume of $0.42 \mathrm{ml} / \mathrm{kg}$.

Administration by gavage was chosen for its simplicity, low cost and adequacy to the study ${ }^{14}$.
In group $\mathrm{C}$ animals saline $0.9 \%$ via gavage was used, a volume of $0.2 \mathrm{ml}$ once a day. The period of administration was equal to that by oil. The animals in this group were examined for the possibility of interference from stress due handling and/or gavage.

The administration of oil or saline was performed on the same day of the surgery and for more 7,14 or 28 days, depending on the subgroup of each animal, using gavage with the animal previously sedated by Halotane inhalation vaporization. On the rats daily physical examination were observed the general conditions and the appearance of the operative wound, for the possible occurrence of bleeding, infection, dehiscence of the skin suture and/or evisceration.

Euthanasia was performed on 20 animals (10 in each subgroup) on postoperative days 7, 14 and 28, by respiratory failure induced by hypercapnia. Access to the abdominal cavity was then obtained by paramedian ventral incision to the left $(2 \mathrm{~cm}$ from the midline). Then any found adhesions were shattered, removing the intestinal segment containing the anastomosis area, $1 \mathrm{~cm}$ proximal and $1 \mathrm{~cm}$ distal from the suture line, which was named specimen (CP) and forwarded to stress testing.

\section{Stress assessment}

The surgical specimens had their eventual fecal content removed with saline $0.9 \%$, being maintained immersed in the same solution and right after that they were submitted to rupture strength analysis.

The mechanical analysis of the specimens was performed by tensile test of the anastomosis operated automatically by tensile assay universal mechanical-eletronic equipment. For tensile strength assessment, each animal specimen were fixed, manually and individually, in tensile equipment adaptable pressure clamps, to held the anastomosis on its medium section equidistant from its ends (Figure 3).

The tension was developed with a constant speed of $50 \mathrm{~mm} /$ minute using a load of $10 \mathrm{~kg}$ and the equipment enabled $50 \mathrm{~g}$ sensibility with force limit of $4500 \mathrm{Kgf}$ until total breakdown of the specimen anastomosis with $0.5 \%$ margin of error until its total rupture (Figure 4).

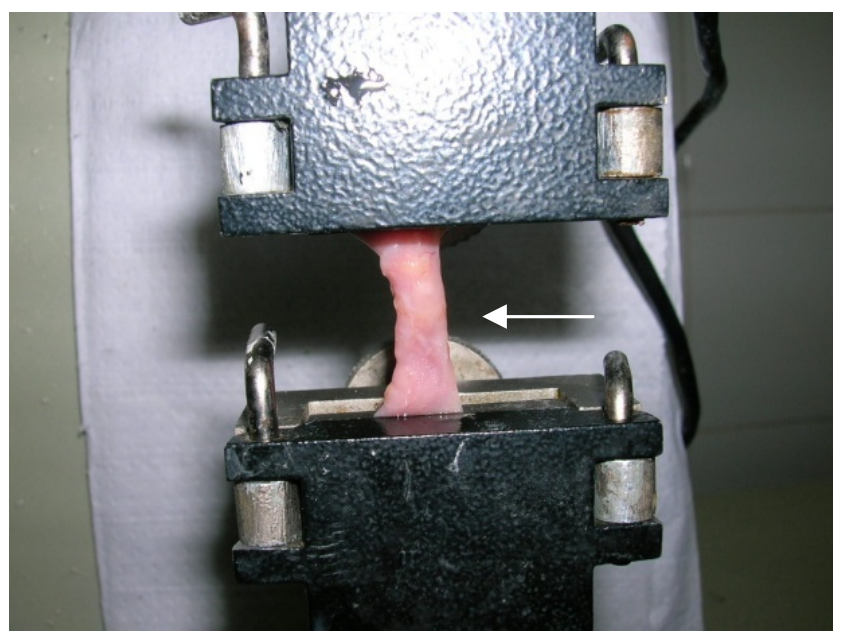

FIGURE 3 - Specimen on the tensile equipment. The arrow indicates the suture line. 


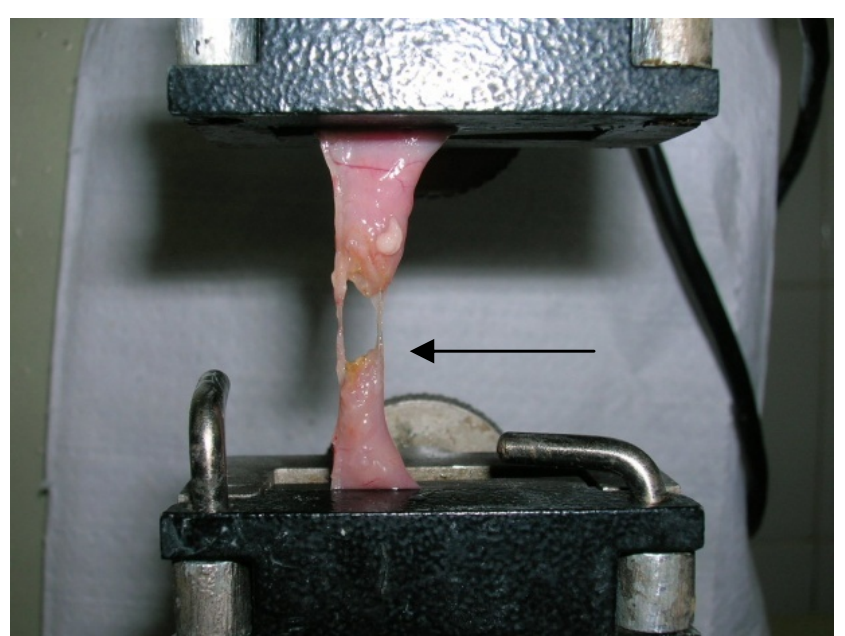

FIGURE 4 - Arrow showing the exact time of anastomosis rupture.

All specimens were tested at time intervals up to two hours after its resection and the results acquisition occurred through TESC software, version 2.0, coupled to the system that allowed calculation of each specimen anastomosis maximum stress, maximum tensile strength, and total rupture strength, as well as the graphical analysis of the event. The maximum tensile strength (FMT) was defined as the maximum force supported by the anastomosis immediately before the start of the rupture and the total rupture strength (FRT) was considered the force required to break through the anastomosis, being kilogram-force these parameters units. The maximum stress (TM) was considered the maximum stress supported by the anastomosis immediately before the rupture, in millimeters of mercury.

It was excluded from the present study the samples in which it was not possible to examine all the variables previously determined.

\section{Statistical analysis}

The results obtained in the study were expressed by means, medians, minimum values, maximum values and standard deviation. To compare the groups at each assessment time, the Student $t$ test for independent samples was used. To compare the assessment times within each group, the variance analysis model and the LSD test for multiple comparisons was used. Variables normality condition was assessed by Shapiro-Wilks test. Values $\mathrm{p}<0.05$ indicated statistical significance.

\section{Results}

All samples were collected without any harm to the specimens, the suture lines were found in perfect condition, with no dehiscence or fistulas. Besides diarrhea, observed in 4 rats from the oil group, no other side effects were found.

In the three study variables (TM, FRT and FMT) the results of comparisons between groups indicated that, for the three assessment times ( 7,14 and 28 days) there was no significant difference between the oil and control groups.

For the variables MT and FMT, in the control group, significant differences were found between the three assessments times ( $p=0.007$ and $p=0.004$, respectively). Similarly, in the oil group, significant difference was found between the three assessments times $(\mathrm{p}<0.001$ for both variables $)$. For the FRT variable within the control group, there were no significant differences between the three assessments $(\mathrm{p}=0.306)$. But for the oil group significant difference was found $(\mathrm{p}=0.002)$. Thus, the times were compared two by two. Figures 5-7 illustrate the values found for these variables within each group.

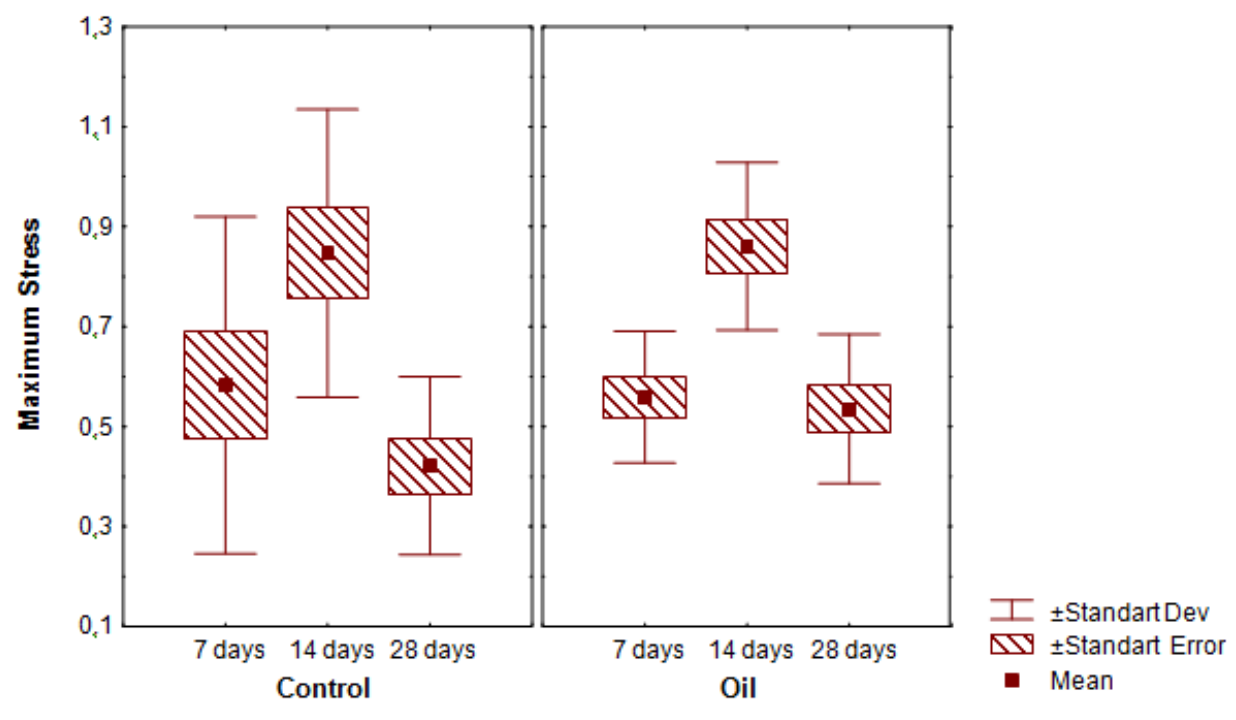

FIGURE 5 - MS variable. It presents significant difference between day 7 and 14 and between day 14 and 28 for both groups. 


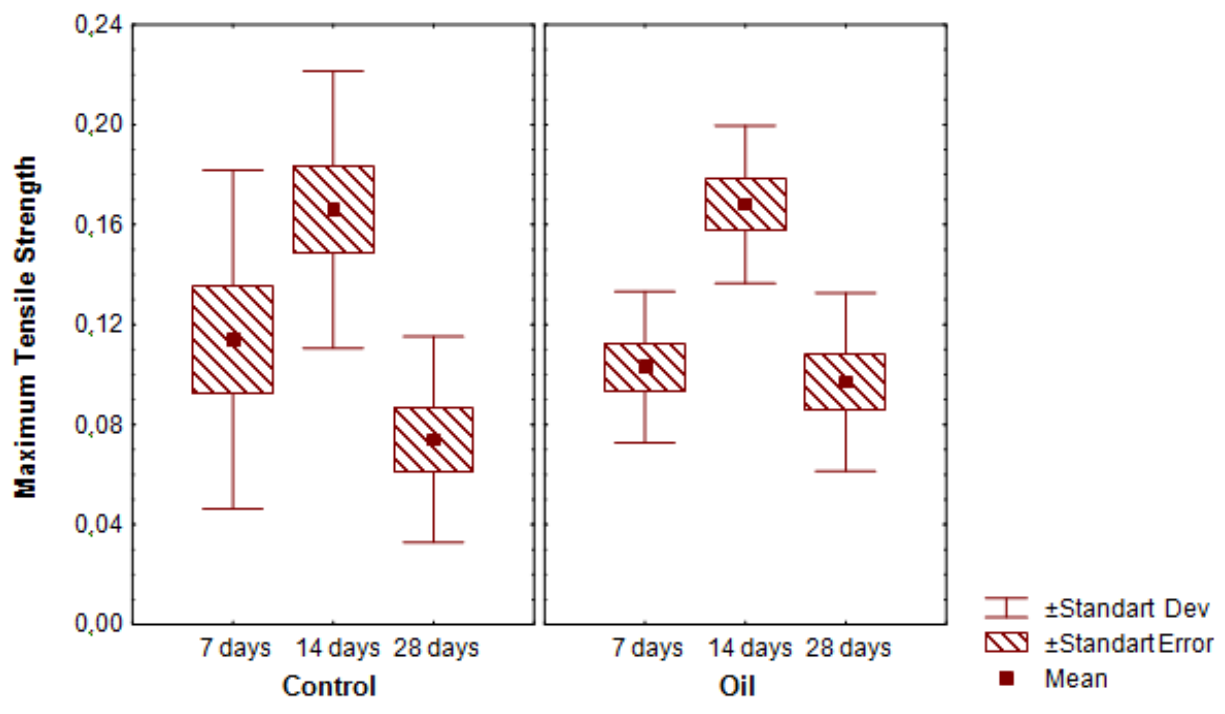

FIGURE 6 - MTS variable. It presents significant difference between day 7 and 14 and between day 14 and 28 for both groups.

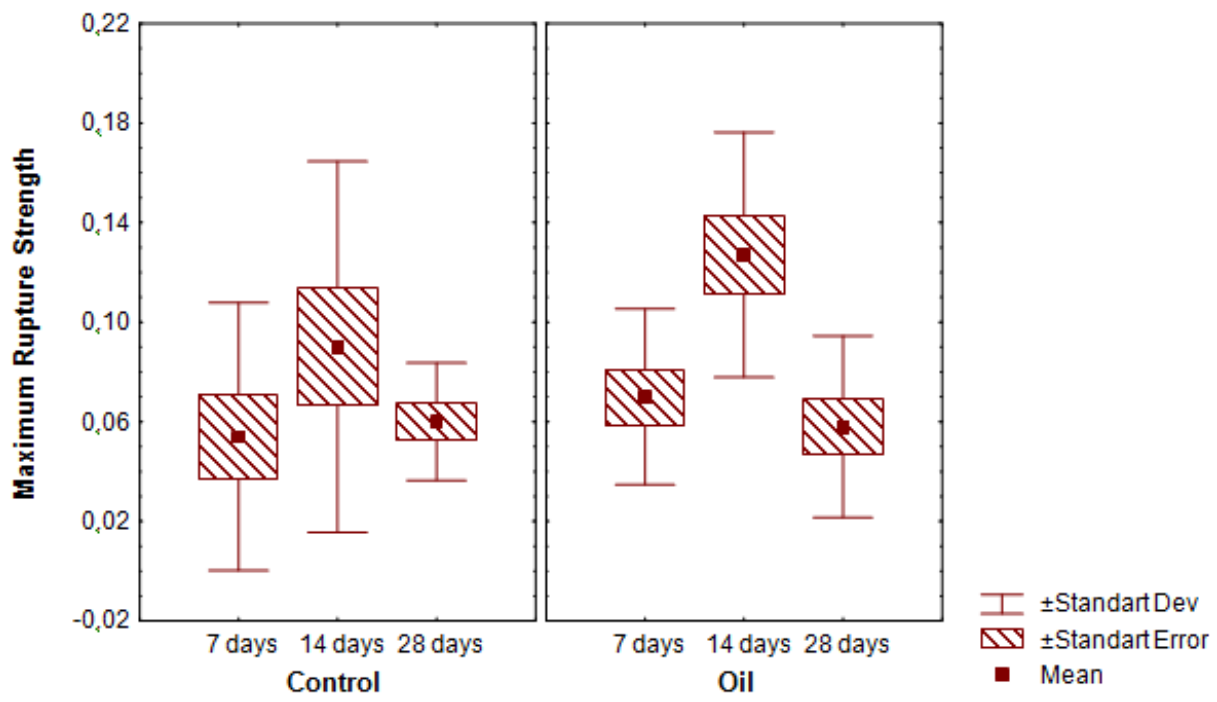

FIGURE 7 - MRS variable. It presents significant difference between day 7 and 14 and between day 14 and 28 for both groups just for oil group.

\section{Discussion}

Suture dehiscences occur in $3 \%$ to $20 \%$ on gastrointestinal tract surgery, and accounts for the high morbidity and mortality of these patients ${ }^{1}$. For this reason, numerous studies on the intestinal epithelium healing process in animal models have been performed in order to reduce this complication dreaded by surgeons.

We are still moving slowly on this direction, in search for new techniques and safer and more effective substances to accelerate tissue repair. In recent years, researchers have found in the Brazilian flora some substances with potential healing effect in colonic anastomosis ${ }^{2,15}$, but the results are not yet considered completely safe. In contrast, Copaíba Oil, which has long been used in the Northern and Northeast Brazil for different therapeutic purposes, such as anti-inflammatory, healing of wounds and laxative $\mathrm{e}^{8-10}$ has been gaining attention in the scientific community and has been target of numerous studies on their physicochemical properties with the aim to develop drugs capable of stimulate the surgical repair.

Some substances such as diterpenes, sesquiterpenes, kaurenoic and polyaltic acid have already been isolated from the pure oil and subjected to tests that proved its healing and antiinflamatory action ${ }^{7}$. Its action on the superficial skin has already shown beneficial effects, accelerating the tissue repair process ${ }^{16}$. However, little is known about its effects on the intestinal epithelium.

For this reason, this study sought to investigate the healing effects of Copaíba Oil on small intestine anastomosis, analyzing the mechanical strength of the anastomotic scar.

According to the results obtained and analysis of the variables in question, it was found no difference between the control and the oil group at the different dates of assessment, indicating that Copaíba oil, apparently, has no effect on the intestinal mucosa, unlikely as on the skin ${ }^{16}$. 
However, when compared within each group, the assessment times presented significant difference on the specimens MT and FMT between 7 and 14 days and 14 and 28 days, suggesting that time is a more important factor to the increased mechanical strength of the anastomotic scar than the actual action of the oil.

Nothing is known about the anastomotic scar morphology pattern concerning the collagen and fribroblasts proliferation on the oil effects, being needed more studies performed for this purpose. However, for the mechanical testing proposed by this study, Copaíba oil has proven to be not effective in increasing the anastomosis strength, the desired effect in any intestinal surgery due to high risks of complications.

\section{Conclusion}

For the mechanical tests proposed by this study, Copaíba oil didn't show any effectiveness in increasing the anatomosis strength.

\section{References}

1. Prado FOR, Fontes CER, Seidel AC, Tomasi MDA, Tomasi HDA. Anastomose colônica com adesivo de fibrina em ratos diabéticos. Rev Col Bras Cir. 2008;35(5):329-33.

2. Goes ACAM, Rodrigues LV, Menezes DB, Grangeiro MPF, Cavalcante ARMS. Análise histológica da cicatrização da anastomose colônica, em ratos, sob ação de enema de Aroeira-do-sertão (Myracrodruon urundeuva fr. all.) a 10\%. Acta Cir Bras. 2005;20(2):144-51.

3. Golub R, Golub RW, Cantu R Jr, Stein HD. A multivariate analysis of factors contributing to leakage of intestinal anastomoses. J Am Coll Surg. 1997;184(4):364-72.

4. Baffa LP, Garcia RLS, Campos AD, Rocha JJR, Feres O. Efeito da anemia aguda na cicatrização de anastomoses colônicas. Estudo experimental em ratos. Rev Bras Coloproctol. 2005;25(1):24-30.

5. Lauand F, Feres O, Rocha JJR, Campos AD, Carvalho FG. Efeito da hipovolemia sobre a cicatrização de anastomoses colônicas. Estudo Experimental em Ratos. Rev Bras Coloproctol. 2004;24(4):317-21.

6. Biondo-Simões MLP, Ioshii SO, Zazula AD, Biondo-Simões R. $\mathrm{O}$ processo de cicatrização influenciado pelo hipotireoidismo e pelo envelhecimento. Estudo da cicatrização de anastomoses intestinais, em ratos. Acta Cir Bras. 2005;20(1):113-9.
7. Tappin MRR, Pereira JFG, Lima LA, Siani AC. Análise química quantitativa para a padronização do óleo de Copaíba por cromatografia em fase gasosa de alta resolução. Quim Nova. 2004;27(2):236-40.

8. Basile AC, Sertié JA, Freitas PC, Zanini AC. Anti-inflammatory activity of oleo-resin from Brazilian Copaifera. J Ethnopharmacol. 1988;22(1):101-09.

9. de Lima Silva JJ, Guimarães SB, da Silveira ER, de Vasconcelos PR, Lima GG, Torres SM, de Vasconcelos RC. Effects of Copaifera langsdorffii Desf. on ischemia-reperfusion of randomized skin flaps in rats. Aesthetic Plast Surg. 2009;33(1):104-09.

10. Gomes NM, Rezende CM, Fontes SP, Matheus ME, Fernandes PD. Antinociceptive activity of Amazonian Copaiba oils. J Ethnopharmacol. 2007;109(3):486-92.

11. Brasil. Lei Federal n. ${ }^{\circ} 11.794$, de 8 de outubro de 2008. Regulamenta o inciso VII do $\S 1$ o do art. 225 da Constituição Federal, estabelecendo procedimentos para o uso científico de animais; revoga a Lei no 6.638, de 8 de maio de 1979; e dá outras providências. Disponível em http:// www.planalto.gov.br/ccivil_03/_Ato2007-2010/2008/Lei/L11794.htm. Acesso em 29 out. 2009.

12. Brasil. Decreto n. ${ }^{\circ} 6.689$, de 15 de julho de 2009. Dispõe sobre a composição do Conselho Nacional de Controle de Experimentação Animal - CONCEA, estabelece as normas para o seu funcionamento e de sua Secretaria-Executiva, cria o Cadastro das Instituições de Uso Científico de Animais - CIUCA, mediante a regulamentação da Lei no 11.794, de 8 de outubro de 2008, que dispõe sobre procedimentos para o uso científico de animais, e dá outras providências. Disponível em http:// www.planalto.gov.br/ccivil_03/_Ato2007-2010/2009/Decreto/D6899.htm. Acesso em 29 out. 2009.

13. Azevedo JLMC, Silva CEP, Azevedo OC, Simões MJ, Kobayashi LA, Kozonara M. Técnicas de sutura do tubo digestivo em plano único com nós atados no lume, em cães: pontos simples totais versus pontos extramucosos. Acta Cir Bras. 2005;20(2):168-73.

14. Brito MVH, Oliveira RVB, Silveira EL, Reis JMC, Noguchi A, Epaminondas WA, Moraes MR. Aspectos microscópicos do fígado de ratos após administração do óleo de copaíba. Acta Cir Bras. [serial online] 2000 Apr-Jun;15(2). Disponível em URL: http://www.scielo.br/acb.

15. Servin SCN, Torres OJM, Matias JEF, Agulham MA, Carvalho FA, Lemos R, Soares EWS, Paulo Roberto Soltoski PR, Freitas ACT. Ação do extrato de Jatropha gossypiifolia L. (pião roxo) na cicatrização de anastomose colônica: estudo experimental em ratos. Acta Cir Bras. 2006;21(3):89-96. 16. Brito NMB, Simões MJ, Gomes PO, Pessoa AF, Melo MCF. Aspectos microscópicos da cicatrização de feridas cutâneas abertas tratadas com óleo de copaíba em ratos. Rev Para Med. 1999;13(1):12-7.

Conflict of interest: none Financial source: none

\section{Correspondence}

Ernesto Comelli Junior

Rua José Palú, 683 - B1 04/303

81020-050 Curitiba - PR Brazil

Phone: (55 41)8402-8905

ernestocomeli@yahoo.com.br

Received: January 20, 2010

Review: March 23, 2010

Accepted: April 28, 2010

\section{How to cite this article}

Comelli Júnior E, Skinovski J, Sigwalt MF, Branco AB, Luz SR, Baulé CP. Rupture point analysis of intestinal anastomotic healing, in rats, under the action of pure Copaíba (Copaifera Iangsdorfii) oil. Acta Cir Bras. [serial on the Internet] 2010 July-Aug;25(4). Available from URL: http://www.scielo.br/acb 